\title{
A Short Review of The Electronic Banking System
}

\author{
Yadgar Hama KHAN \\ Kaposvár University, Faculty of Economic Science, H-7400 Kaposvár Guba S. u. 40. \\ Economic Department, College of Administrations and Economics, University of Sulaimani, \\ Kurdistan Region, Iraq
}

\begin{abstract}
The necessity of E-Banking services with the new generation's lifestyle today is reached at different levels of technology innovations. This paper aims at directing and contributing to E-Banking by exploring and analysing the current situation of commencement on E-Banking and its acceptance confidently. This paper presents an intensive summary review of a doctorate research by the author about E-Banking acceptance in the Kurdistan Region of Iraq in which 38 studies among 110 published papers were selected on E-Banking between 2002-2016. The studies seek to draw reliable conclusions from their data to identify the influenced factors on the acceptance and adopting of EBanking system. To analyse the capacity and results of these studies, an analysis was conducted on the most influenced factors, powerful acceptance theories employed in these studies, the sample unit, respondent size and the location of the investigation. The results showed that the factors of security, perceived ease of use and trust had the higher frequencies among the others. The most used model in these studies was TAM model with a great satisfaction results by the researchers and bank institutions. The respondents of these studies were between 44 and 3000 and the major sample unit is bank customers and the majority of studies were from Iran, which are 13 studies. It was found that other theories (UTAUT and UTAUT 2) were less attractive to researchers in their studies. Therefore, the most results are based on the outcomes of TAM models. However, there are limitations of the outcomes by this study for reviewing limited papers, some shortcomings in constructing the links between the E-Banking channels with the influenced factors and there is supremacy of the higher frequency of using TAM on the results. Further works are recommended to study security, perceived ease, and trust using (UTAUT and UTAUT 2) in the countries with large population strata.
\end{abstract} Keywords: E-Banking, TAM, UTAUT, Bank customers, acceptance, adoption, security, perceived ease of use, trust

\section{INTRODUCTION}

There are considerable developments in banking systems all around the world as a response to the changes in people's current lifestyle. One of the major changes is introducing the new technology into the system and accepting it, which is called EBanking.

Electronic banking (E-Banking) is a new kind of reform in banking services that plays an essential role in achieving electronic government. This system was first implemented in the United States in 1995 (FFEC, 2003), developed quickly among other business units as a wave to bring convenience and economy for customers and 
such new challenges for officials as security, inaccessibility to networks due to faults, maintenance cost, updating databases, as well as planning and executing modern economic policies.

Therefore, E-Banking includes all banking services based on the implementation of an electronic system. (Azad et al, 2013a). It has become an important phenomenon in the banking industry and it will continue as more progress is made in information technology. The financial industry thus is gradually experiencing transformation from cash-based system to a "paperless" system, which is more convenient, and reliable (Gbadeyan and Akinyoseye-Gbonda, 2011).

However, the rapid development of the market for electronic devices and tools led the researchers to create various definitions for E-Banking. Although, they do not differ in the principle, they are based on the research topic and area of investigations.

This wide range of applicability of E-Banking suggests an inclusive definition to cover all concerns in the system. It is an alternative method to the traditional banking system through a process of running an electronic media by banks to conduct all possible services between them and their customers. This is to allow to perform financial transactions inside and outside their institutions through the internet, wireless network, automated teller machines (ATM) using a debit card, a direct deposit, a direct payment, computers, mobile phones, telephones or digital televisions. The services include: access to their accounts, to take control of their money, to pay their bills and transfer money from one account to another account rather than by cash or checks.

Despite such advantages, for individuals in countries with the E-Banking system, the acceptance and adoption of the system is not easy or guaranteed just because they are in possession of the electronic equipment or availability of secure access to the networks. There are numbers of factors which have their impact on the acceptance of the system like attitude, trust, security, usage of use, and accordingly, this paper looks for understanding the available factors and investigating to reveal the obscure factors behind the apathetic willing towards this system through a systematic Literature review.

\section{LITERATURE REVIEW}

There is a very rapid increase in research about accepting and adopting E-Banking all around the world. E-Banking is still offering the competitive advantages such as cost reduction; better user service; fewer hours and less paper work; and faster and updated information.

The system is not relying entirely on the services by Internet technology and their ability to speed up the banking process. The cooperation between bank institutions and researchers produced a large accumulation of studies which hastened the links between the bank duties and the customers through different styles of studies like empirical study, questionnaires and data collections from different groups of people and from different countries. The researchers have sought the ways to develop E-Banking system by analysing the advantages of the system, utilizing the services by bank institutions for attracting the customer's interest to persuade their demands to achieve their 
acceptance. The studies aimed at introducing several factors and analysing their impacts on accepting and adopting the system; some of them are related to the psychological factors and others to the security and economic stability. The diversity of the factors are based on the situation of a particular bank in a particular country, as the stage of adoption or acceptance of this electronic system governs the style of the study and its outcome is to develop or progress the system actively. The idea of E-banking can be understood as a combination of four fields: information technology, finance, marketing and service management (Hanafizadeh et al. 2013).

These researches are categorized under non- empirical and empirical researches (Alavi and Carlson, 1992); non-empirical researches are those based on the author's critical view for other outcomes and analysis by means of literature review, principles, and comparisons of two methods of analysis or another type of contribution. Empirical researches are focusing on the analysis of data observations through different techniques such as field survey, questionnaires, case studies and interviews. Both methods supported their approaches and results by applying the most predominated theories and models like TRA, TAM and UTAUT, which were followed successfully.

To review these studies, it is more convenient to classify them as follows:

\section{The advantage and services of the E-Banking system}

Howcroft et al. (2002) have categorized the retail banking services into four groups: current account, insurance-based, credit-based and investment-based services. Whereas, Chou and Chou (2000) shaped the online banking in five basic services: viewing account balances and transaction histories, paying bills, transferring funds between accounts, requesting credit card advances and ordering cheques.

Thornton and White (2001) and Black et al. (2002) focused on the influence by the variety of distribution channels in expanding the banking services. They compared the outcome from seven distribution channels of ATM, credit card, cheque, human teller, telephone and Internet. They reached an agreement that consumers' channel options in banking services were determined by consumer, product, channel and organizational characteristics, in which the consumer channel and the alternate choice rather than the classical method have their particular interaction with the banking system. They understood that the usage of different channels by the users is affected by their knowledge, computers, Internet availability, technology and convenience.

\section{Studies on bank facilities and customer's view point towards using the system}

The important step towards the implementation of E-Banking system is studying the costumer's acceptance and adopting the system confidently. Thus, a large number of researches were conducted or still under further studies to study the most influenced factors on the adoption and acceptance of this system despite their proved advantages. These factors include attitude, age, race, religion, security risk, trust, awareness, quality, satisfaction, efficiency, convenience, technology service accessibility, perceived usefulness, perceived ease of use, cost, fee, household income, education reliability, compatibility, size of the bank, etc. 
For western countries and the USA, the major challenge of studies in adopting this system was concentrated on the factors of ease of use or learning technology, trust, privacy and security (Sathye. 1999, Moutinho and Smith (2000), Lymperopoulos and Chaniotakis (2004), Floh and Treiblmaier (2006), Poon (2007), Sanchez-Franco (2009), Aderonke and Charles K (2010), Faroughian, et al. (2012), Ma and Zhao (2012), Capece and Campisi (2013), Johnson (2014), Rodrigues et al. (2016), Hoeble et al. (2017), etc.

The analyses of these studies are discussed in the next section showing the factors concerned and their frequency, unit of analysis, results and recommendations.

\section{The most influential factors in the developing and developed countries}

The acceptance and adoption of this system are more complicated for several countries in the world which are surrounded by special circumstances. There are obstacles coming from the peace statute internally and on the border with other neighbors, demography, geography, economic stability, settlement of citizens, security, people's incomes, traditions and religious concepts.

Fitzergerald (2004) analyzes numbers of studies to discover recent and possible customers' awareness on online banking. He has concluded that there is common awareness concerning online banking with disregard to demographic, geographic or psycho graphic characteristics. He disputed that among the major 'non-adoption' areas are the security factor and lack of knowledge of online banking.

Most of the Iranian studies were about customers' adoption of Internet banking services (Mirza at al., 2009), factors affecting the adoption of mobile banking (Hanafizadeb et al., 2012), developing an understanding of Iranian customer's attitude and adoption of Internet banking services (Mirza et al. 2009), an investigation of the level of user's acceptance of electronic banking among some customers of banks in Iran (Abadi and Nematizadeh, 2012). An investigation on important factors influencing electronic banking for developing exports in Iran are for example infrastructure, advanced services, methods, information knowledge and design (Arad et al. 2013b) and word of mouth impact on the adoption (Mehrad and Mohammadi, 2016). In Jordan, despite of the fact that it is considered as a low-income country, the researches have helped increase the interest of its citizens to use this system since 2000. (Alalwan et al., 2015). In studies conducted to examine the main factors predicting the Jordanian customers' intention and adoption of telebanking, Al-Rfou (2013) emphasizes the use of e-banking from the viewpoint of electronic services staff and the phase which impacts it, such as the acceptance of the system by clients, and how clients can be persuaded to make the most of the financial activity by using e-banking. Salbieh et al. (2011) proposed and validated a framework that can be used for assessing the level of banks' readiness to provide e-banking services in Jordan. Al-Somali et al. (2008) examined the factors that encourage customers to adopt online banking in Saudi Arabia. They found that the quality of the Internet connection, the awareness of online banking and its benefits, the social influence and computer self-efficacy had significant effects on the perceived usefulness (PU) and perceived ease of use (PEOU) of online banking acceptance. Education, trust and resistance to change also have a significant impact on the attitude towards the likelihood of adopting online banking. 
In Malaysia, Emovianti et al. (2012) found that the objective of utilizing Internet banking was led by self-efficiency and some connection between effectiveness, userfriendliness, trust, and self-efficiency. In Singapore, Liao and Cheung (2002) studied the most influenced factors in the developing countries. They found that the important quality features of E-retail banking to produce a noticeable willingness to use this system by the individuals were coming from the customer's potential anticipation about accuracy, security, transaction time, user-friendliness, user involvement, convenience and willingness to use by consumers. In Yemen, Al-Ajam and Nor (2015) believed that a proportional advantage, user-friendliness and trust in E-Banking influenced the attitude of people to accept the system. In Canada, Montazemi and Qabri-Saremi (2013) concluded that trust was a more apparent factor compared to assumed effectiveness and user-friendliness in shaping clients at the primary stage of accepting E-Banking exploitation. In Nigeria, an empirical study was conducted by Aderonke and Charles (2010) and they investigated the level of users' acceptance of the electronic banking services supported by suggesting the factors that determine users' behavioral intentions to use electronic banking systems in Nigeria. The results of this research showed that ATM still remained the most widely used form of the e-Banking service. Banks' customers are considered to be the active users of the E-banking system because it is convenient, easy to use, time-saving and appropriate for their transaction needs. Also, the network security and the security of the system in terms of privacy are the major concerns of the users and constitute a hindrance to intending users.

\section{The applied theories and models}

Several models and theories have been developed as a dual effort between researchers and bankers to shape the progress of technology applications to their advantages by analysing the most important factors that have influences on the consumer's acceptance and adoption of new technologies. These models have been designed for a particular institution or the study of the factors concerned. However, there are several theories and models in literature which have been employed to explain the relationships between the factors affecting the acceptance and adoption dominancy and user's attitude and willingness as shown in Appendix (1). Among them, there are three very well-known models which are the following: Technology Acceptance Model (TAM) by (Davis in 1989, Davis et al. (1989), Poon (2007), Aderonke A and Charles K. (2010), Abmad et al. (2011), Jalal et al. (2011), Johar and Awalluddin (2011), Abadi and Nematizadeh (2012), Ahmadi and Afrouzi (2012), Moga, et al. (2012), Raida and Néji. (2013), El-Qirem (2013), Sanayei and Saneian (2013), Alikhani and Davarzani. (2014), Mansour et al. (2016), Rodrigues et al. (2016), etc....) which is the adaptation of the Theory of Reason Action (TRA), which was proposed by Fishbein and Ajzen in 1975 (Ahmad et al. 2011, Ahmadi and Afrouzi. 2012, Rodrigues et al. 2016, etc....) and Unified Theory of Acceptance and Use of Technology (UTAUT) developed by $V$ enkatesh et al. in 2003. This theory is used very widely for its simplicity, parsimony and robustness (Oshlyansky et al. 2007, AbuShanab et al., 2010, Yuen et al., 2010, Foon and Fah, 2011, Venkatesh et al. 2012, El-Qirem 2013, Tarbini et al., 2014). The list of the theories used in these reviewed papers is given in Appendix 1. 


\section{Selection of studies used for the acceptance and adoption of E-Banking}

The purpose is to solve the system of E-Banking thoroughly or consider any aspect in the system. According to (Venkatesh and Brown, 2001) E-banking should be accepted, trusted, adopted and used. However, the operation of E-Banking in some courtiers is still out of the system where there are many factors beyond the initiation of this technology. The factors are numerous but the most effective factors are scattered in literature and utterly specified to the country where the studies were conducted.

In this paper, thirty-eight studies are reviewed in which the acceptance and adoption of E-banking system service were investigated by using different theories, data sample, sample size, diameters and other details. Appendix 1 and 2 include summaries of the used models, unit of samples and brief results.

\section{RESEARCH METHODOLOGY}

The aim of this study is to review and analyse literature which is related to the acceptance and adoption of the E-banking system service.

The methodology of this work was built upon five stages. The first stage was to find out the required area where the lack of investigations dominate the empirical research on the electronic banking system. This was obtained through using some important keywords (like E-banking, TAM, UTAUT, acceptance, adoption, security, perceived ease of use, trust) in a massive search in some databases and google scholar. Then, the second stage was to construct a framework for research in two parts, one for reviewing the relative papers and the second was for concentrating on the statistical analysis usage (Searching Engines, Theories, Factors, Samples, Size, and Locations).

At the third stage, the review was concentrated on the keywords in the empirical researches and the length of some publications were solved by paying a good attention to the parameters which have major influences on the system as long as adoption and acceptance are related. The fourth stage became ready from the preceding stages, working on charting and plotting the relationships of the main parameters with their frequencies. All data were tabulated with sufficient information like author, country, number, and type of samples, theory, parameters, and outcomes by the authors.

At the fifth stage, main conclusions were drawn which were based on the third and fourth stages, as the frequencies gave clear tendencies towards the impacts of particular parameters on the adoption and acceptance of this system.

According to Venkatesh and Brown (2001) E-banking should be accepted, trusted, adopted and used. However, the operating of E-Banking in some courtiers is still out of the system where there are many factors beyond the initiation of this technology. The factors are numerous but the most effective factors are scattered in literature and utterly specified to the country where the studies were conducted.

A strict search for the much related studies in this area has been carried out in Google scholar and other databases such as Emerald Insight, Science Direct and other sources. A total of 110 studies have been reviewed carefully, then only 38 studies have been considered in this paper written between 2002-2016. Those studies 
were selected and in which the acceptance and adoption of E-banking system were the investigation priority considered. They include different theories and models, data, sample size, geography and more details as shown in Figure 1.

\section{Figure 1}

\section{Search engines}

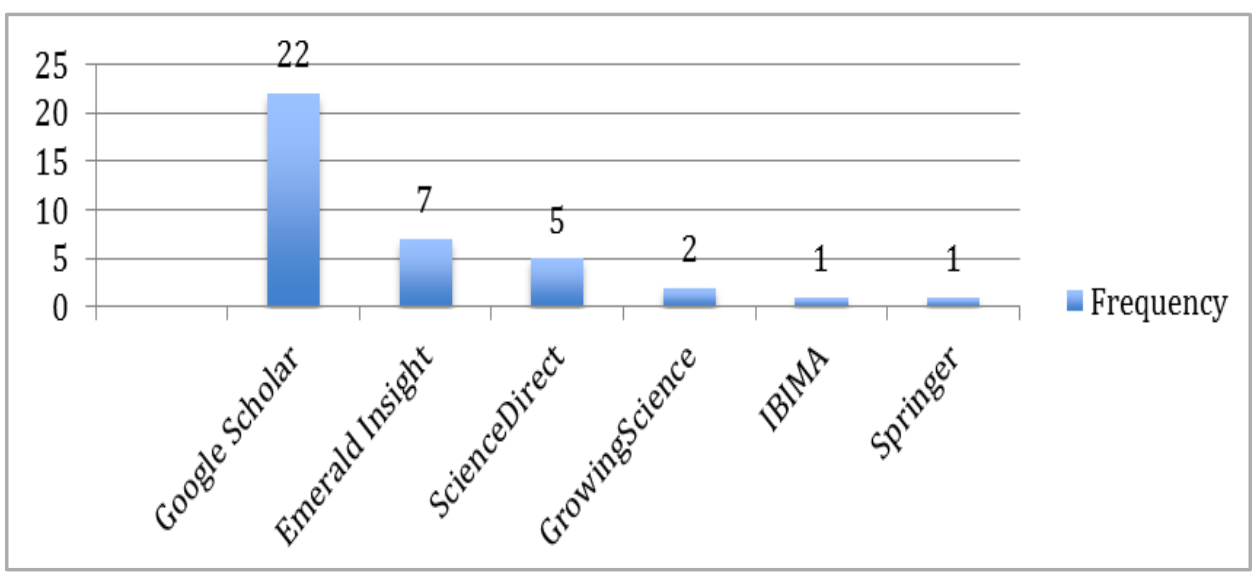

\section{Research objectives:}

- To study the impact of factors (security, perceived ease of use and trust) that play significant roles in the acceptance and adoption of the E-Banking system.

- To analyse the results of the most related studies of the most influenced factors.

- To identify the factors and circumstances which are surrounding the developing countries to adopt this system from those studies that have been conducted by authors from these countries.

- To give conclusions and recommendation for further studies to the developing countries on how to create a better chance for acceptance and adoption in the future.

\section{RESULTS AND DISCUSSION}

The most influential factors in the studies reviewed were the ones which affect the acceptance or adoption of the E-banking system service analysed in terms of their frequency and ranks as shown in Figure 2. It was found that the security, perceived ease of use, trust and quality were the top factors which have their noticeable impacts, it means that these factors have been used by a total of 38 studies to understand the acceptance or adoption of the E-banking system service. On the other hand, the least used factors that have been perceived are value, size of the bank and technologies investigated for the same purpose. The definitions of the corresponding factors in this study are given in Appendix 3. 
Figure 2

Frequency and ranking of factors

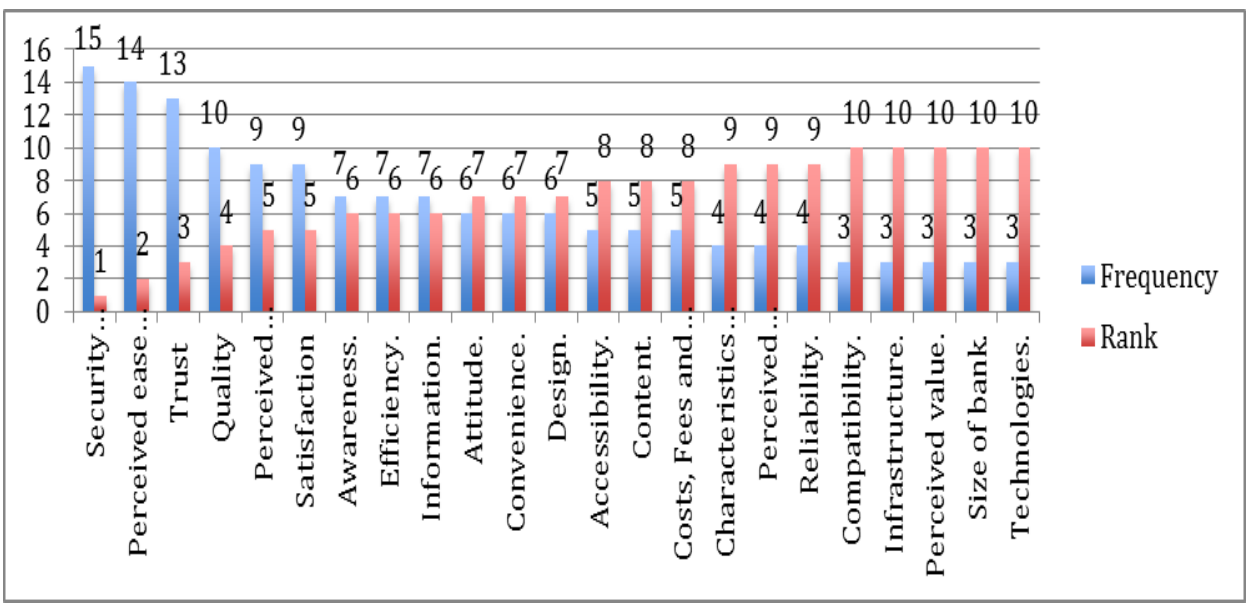

In Figure 3, the most and the least used theories have been shown in these studies. There are 13 studies which used a self-developed model, the rest of 38 studies used models based on social psychology or adoption of new technological theories, out of which 8 studies used TAM, 1 study for each of the rest of the theories has been used in the rest of the studies, which is shown in figure 3.

\section{Figure 3}

\section{Acceptance or adoption theories}

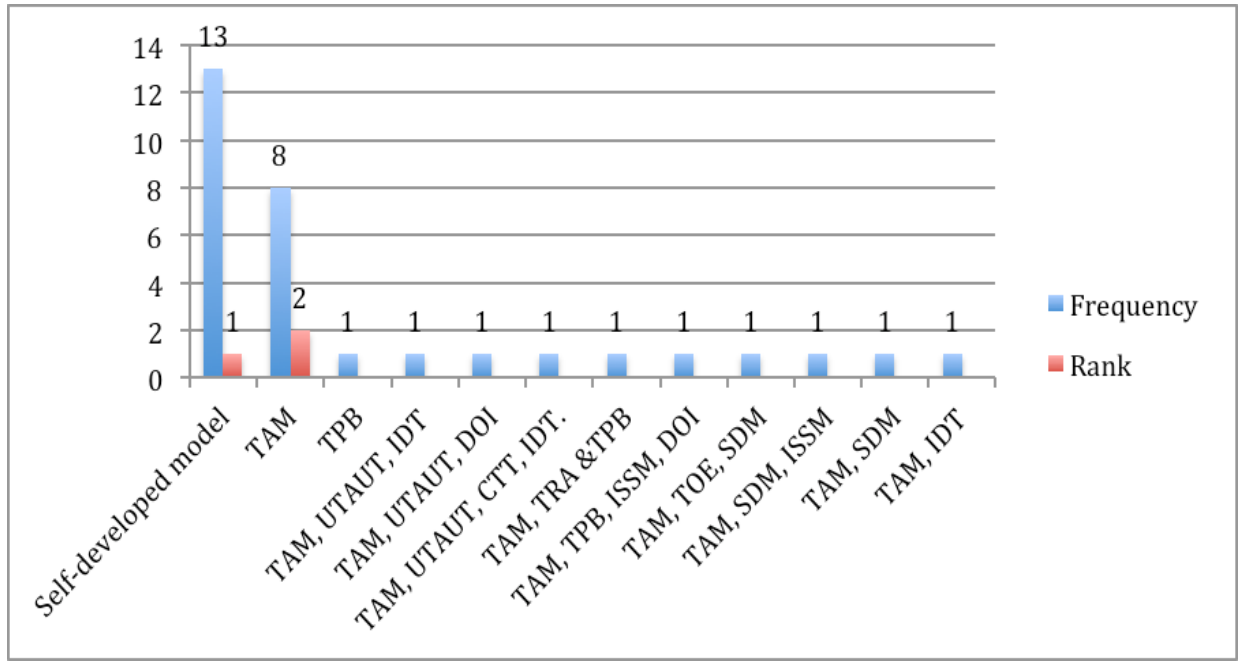


The most powerful acceptance theory ever is Technology Acceptance Model (TAM) compared to other theories that are mostly used and cited for user's acceptance of new technology, as shown in Figure 3. Technology Acceptance Model (TAM) is used in these studies to determine the best practice and user's acceptance of IT/IS, which means studying the expectation of human behavior, Information Communication Technology (ICT), the user's attitude towards and acceptance of a new information system, which is an important tool in measuring the successful adoption of the information system and realizing the reason for acceptance and rejection of new technologies in organizational settings (Davis 1989, Davis et al. 1989).

It has been found that the most dominant sample unit that have been concerned in 38 studies are the customers of E-banking in 29 studies, employees or staffs of Ebanking come next in 6 studies, academic staff and students are the third sample unit in 3 studies, managers or IT managers is the fourth sample unit in 2 studies and business leaders is the fifth sample unit only in 1 study (Figure 4).

\section{Figure 4}

\section{Sample unit of 38 studies}

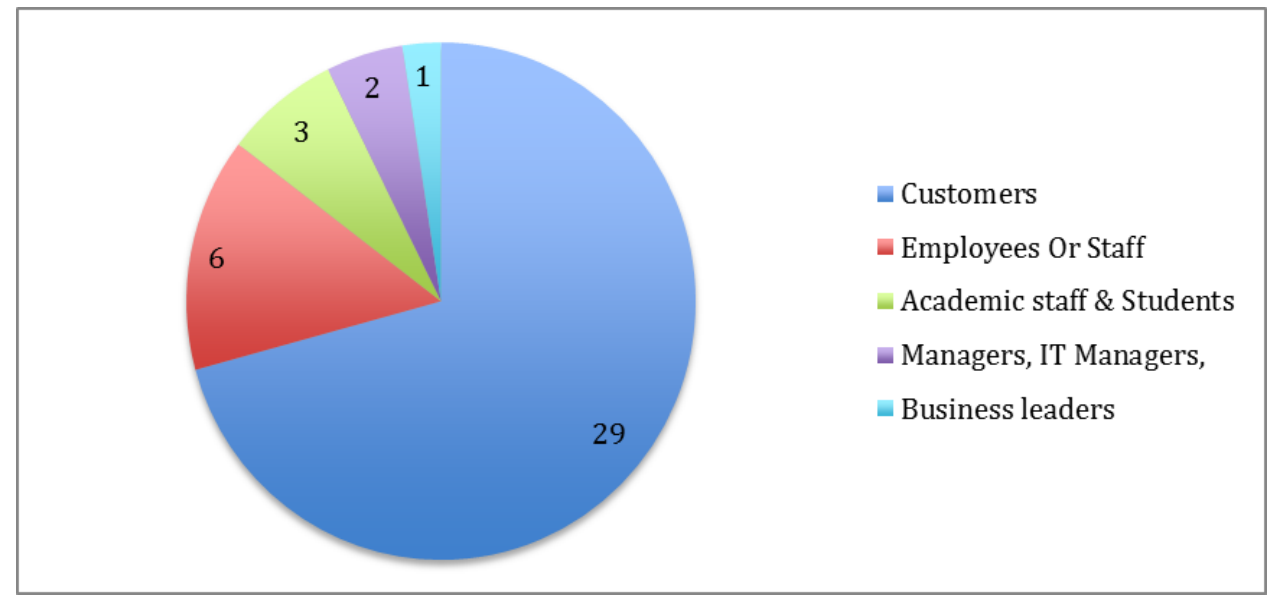

The size of samples is shown in Figure 5 regardless to the underlying factors and employed theory through the numbers of the respondents, which have been considered in the individual study. The numbers are located between 44 and 3000 respondents and the average of a typical study is 401 respondents.

The studies for adopting the E-Banking system in a developing country are given a significant consideration in this study. The location of each study is considered as the place where a survey or data were carried out as given in Appendix 2. In the second appendix, a brief of the reviewed papers' results is explained. From the 38 studies, 13 studies are from Iran, 3 studies are from Jordan and Malaysia respectively, 2 studies are from New Zealand and Nigeria and data collection for each of the rest of studies were located in the rest of the countries, which is shown in Figure 6. 


\section{Figure 5}

\section{The respondents of 38 studies}

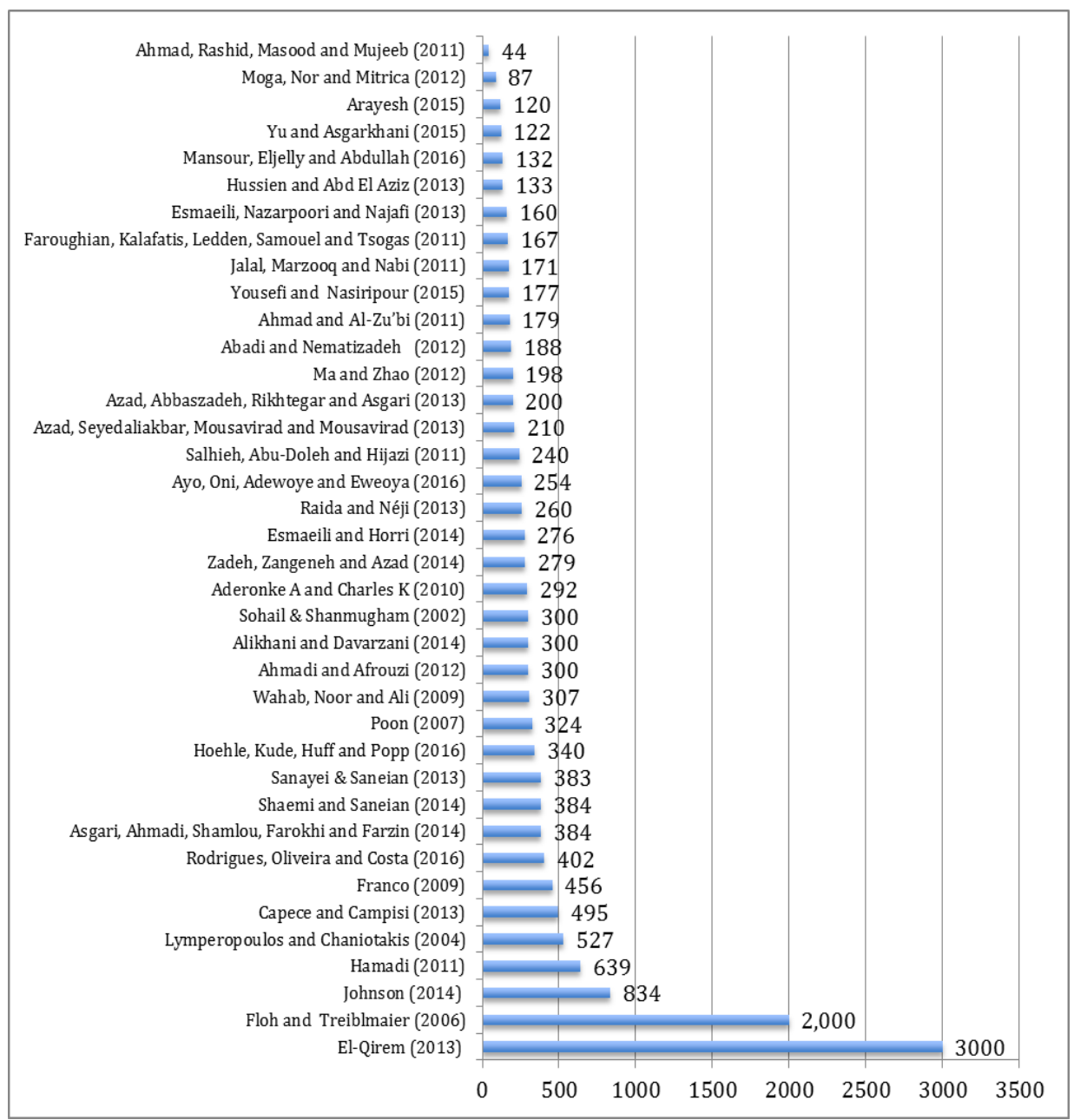

\section{LIMITATION}

It is obvious to review and analyse the literature related to E-Banking; a more extensive study should be accounted for each factor which has influences on the adoption of the system. Despite the fact that the results and conclusions are limited to these 38 studies in this paper, the decisions are rather general and are not precisely given. There are some shortcomings in connecting the E-Banking channels with the influential factors for the developed countries. Also, TAM is taken as the top of the well-known models, which is still one of the widely used theories. It was found that other theories (UTAUT and UTAUT 2) had less interest for researchers in their studies. Therefore, the most results are based on the outcomes of TAM models. 


\section{Figure 6}

\section{The locations of data collection}

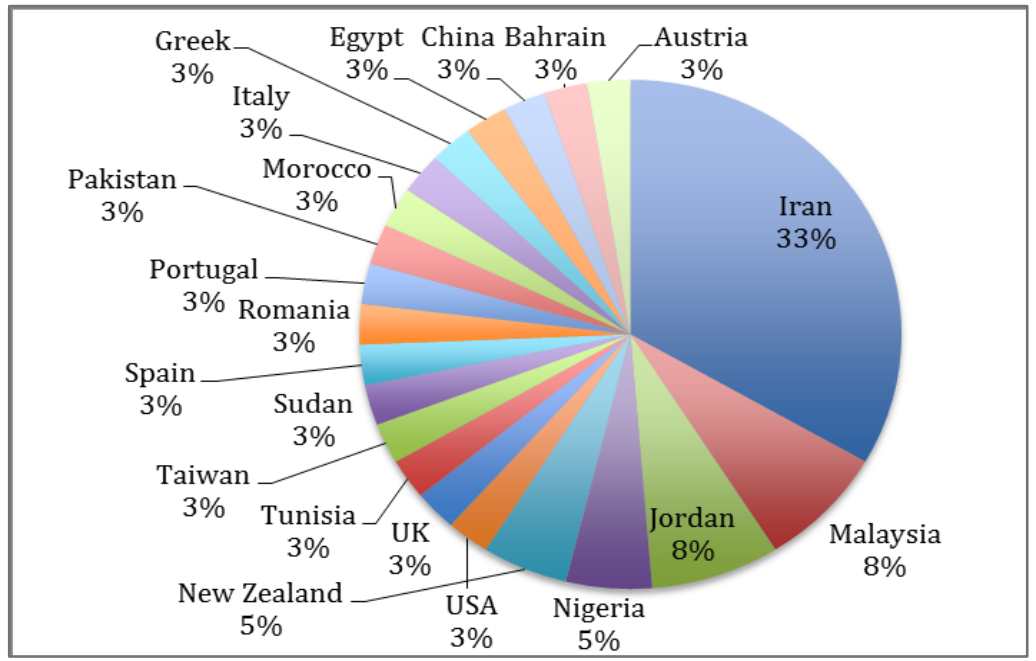

\section{CONCLUSION}

A total of 38 relevant papers among 110 papers published between 2002 and 2016 has been considered in this study. This paper is conducted to review and analyse the main influential factors on the acceptance and adoption of the E-Banking system along with confessing the limits of results and suggesting significant recommendations for further studies. In literature selected search engine and other sources of publishers and journals were used. After examining these papers in details, the analysis was concentrated on four main aspects in terms of a frequency analysis, which have their influence on the acceptance and adoption of this system in different countries worldwide. These aspects are: the most influential factors, powerful acceptance theories employed in these studies, the sample unit, respondent size and the location of the investigation.

The results showed that factors of security, perceived ease of use and trust were the most influential factors in banking regarding the customers' confidence in accepting and using the service for both the developed and developing countries. It has been found that these studies mostly depend on TAM model to explain the high intention to accept and adopt the E-Banking. The employment of TAM was significant compared to TAR and UTAUT. The numbers of respondents of these studies are between 44 and 3000 respondents and the average is 401 respondents.

Bank customers are the majority of the sample size of this study due to the direct relationship between banks and customers. It is believed that the accurate results were obtained by the researchers. Thus, this kind of relationship can provide a better result of the degree of the acceptance of E-banking. 
However, the sample units of these studies are large and heterogeneous. However, apart from the main factors, there are tens of other factors which can be identified to have their particular influence on the adoption of this system. The decisions were definitely depending on the existing circumstances of those countries where the study was conducted.

\section{RECOMMENDATIONS}

This review study directs the attention for further works and recommendations to improve and extend the scope of researches as follows:

There is no decisive criteria index of any factors as a limit to be achieved in the process of acceptance and adoption of this system in the developing countries. All studies concerned very special cases and the results were suited for them. Therefore, it could be great to conduct these kind of studies even with conditional circumstances.

The comparison studies for results by TAM and UTAUT models are missing in literature, so the results for the most influential factors with higher frequencies in this study (security, perceived ease and trust) need further investigation by assessing their results from comparisons between these models. Moreover, the outcome by these models would need to be analysed according to the source of data, sample units and population strata.

Almost all the developing countries in the Middle East and east of Asia have a strong religious background and they have big families and accordingly the age of a large proportion of their populations is between 18 and 35. Consequently, they have their major influence on the acceptance and adoption of this system. Therefore, exclusive studies are needed for the influence of security, perceived ease of use and trust on the different groups of people or population strata using TAM and UTAUT. This can designate the accurate results in accepting and adopting this system for each of population strata and groups.

\section{REFERENCES}

Abadi, H.R.D., Nematizadeh, F . (2012): An Empirical Investigation of the Level of User's Acceptance of E-Banking among Some Customers of Banks in Iran. In: International Journal of Academic Research in Business and Social Sciences, 2. 6. 418-430. p.

AbuShanab, E., Pearson, J.M., Setterstrom, A.J. (2010): Internet Banking and Customer's Acceptance in Jordan: The Unified Model's perspective. In: Communications of Association for Information Systems, 26. 23. 493-524. p. doi: 10.17705/1cais.02623

Aderonke A.A., Charles, A. (2010): An Empirical Investigation of the Level of Users' Acceptance of E-Banking in Nigeria. In: Journal of Internet Banking and Commerce, 15. 1. 1-13. p.

Ahmad A.E.M.K., Al-Zu'bi. H.A. (2011): E-banking Functionality and Outcomes of Customer Satisfaction: An Empirical Investigation. In: International Journal of Marketing Studies, 3. 1. 50-65. p. doi: 10.5539/ijms.v3n1p50 
Ahmad, M.S., Rashid, S., Masood, M.T., UL Mujeeb, E. (2011): E-Banking: A Case Study Of Askari Commercial Bank Pakistan. In: Management and Marketing, 9. 2. 243-254. p.

Ahmadi, A.A., Afrouzi, M. (2012): An empirical analysis on the adoption of electronic banking in the financial institutes using structural, behavioral and contextual factors. In: Management Science Letters, 2. 5. 1669-1682. p. doi: 10.5267/j.msl.2012.04.022

Al-Ajam A.S. Md Nor, K.. (2015): Challenges of adoption of internet banking service in Yemen. In: International Journal of Bank Marketing, 33. 2. 178- 194. p. doi: 10.1108/ijbm-01-2013-0001

Al-Hawari, M., Ward, T., Newby, L., (2009): The relationship between service quality and retention within the automated and traditional contexts of retail banking. In: Journal of Service Management, 20. 4. 455-472. p. doi: 10.1108/09564230910978539

Al-Rfou A.N. (2013): The Usage Of Internet Banking Evidence From Jordan, Asian Economic and Financial Review, 3. 5. 614-623. p. [online] <URL: http://www.aessweb.com/pdf-files/614-623.pdf>

Al-Somali, S.A., Gholami, R., Clegg, B. (2008): Internet Banking Acceptance in the Context of Developing Countries: An Extension of the Technology Acceptance Model. European Conference on Management of Technology. Nice, Sept. 2008.

Alalwan, A.A., Dwivedi, Y.K., Rana, N.P., Lal, B., Williams, M.D. (2015): Consumer adoption of internet banking in Jordan: examining the role of hedonic motivation, habit, self-efficacy and trust. In: Journal of Financial Services Marketing, 20. 2. 145-157. p. doi: 10.1057/fsm.2015.5

Alavi, M., Carlson, P. (1992): A Review of MIS Research and Disciplinary Development. In: Journal of Management Information Systems, 8. 4. 45-62. p. doi: 10.1080/07421222.1992.11517938

Alikhani, A., Davarzani, M.H. (2014): An investigation on factors influencing electronic banking adoption in private banks versus public banks. In: Management Science Letters, 4. 1. 37-42. p. doi: 10.5267/j.msl.2013.12.001

Arayesh, M.B. (2015): Investigating the Relationship between Technical and Legal Factors with Tendency of Villagers to Use E-Banking Services (Case Study: Agricultural Bank Branches in Ilam). In: Procedia - Social and Behavioral Sciences, 205. 529-535. p. doi: 10.1016/j.sbspro.2015.09.068

Asgari, N., Ahmadi, M.H., Shamlou, M., Farokhi, A.R., Farzin, M.. (2014): Studying the Impact of E-Service Quality on E-Loyalty of Customers in the Area of EBanking Services. In: Journal of Management and Sustainability; 4. 2. 126-133. p. doi: $10.5539 /$ jms.v4n2p126

Ayo, C.k., Oni, A.A., Adewoye, O.J., Eweoya, I.O. (2016): E-banking users' behaviour: e-service quality, attitude, and customer satisfaction. In: International Journal of Bank Marketing, 34. 3. 347-367. p. doi: 10.1108/ijbm-12-2014-0175

Azad, N., Abbaszadeh, V., Rikhtegar, M., Asgari, H. (2013a): An empirical investigation on factors influencing on electronic banking for developing export. In: Management Science Letters, 3. 6. 1583-1586. p. doi: 10.5267/j.msl.2013.05.032 
Azad, N., Seyedaliakbar, S.M., Mousavirad, S.S., Mousavirad, S.N. (2013b): An exploration study on factors influencing acceptance of electronic banking industry. In: Management Science Letters, 3. 6. 1783-1788. p. doi: 10.5267/j.msl.2013.05.003

Bai, B., Law, R., Wen, I. (2008): The impact of website quality on customer satisfaction and purchase intentions: Evidence from Chinese online visitors. In: International Journal of Hospitality Management, 27. 3. 391-402. p. doi: 10.1016/j.ijhm.2007.10.008

Black, N.J., Lockett, A., Winklhofer, H., Ennew, C. (2001): The adoption of internet financial services: a qualitative study. In: International Journal of Retail \& Distribution Management, 29. 8. 390-398. p. doi: 10.1108/09590550110397033

Capece, G., Campisi, D. (2013): A Behavioural Model of E-Banking Usage in Italy. In: International Journal of Engineering Business Management, 5. 16. doi: 10.5772/56606

Chou, D.C., Chou, A.Y. (2000): A guide to the internet revolution in banking. In: Information Systems Management, 17. 2. 47-53. p. doi: 10.1201/1078/ 43191.17.2.20000301/31227.6

Davis F.D. (1989): Perceived usefulness, perceived ease of use, and user acceptance of information technology. In: MIS Quarterly, 13. 3. 319-340. p. doi: $10.2307 / 249008$

Davis, F.D., Bagozzi, R.P., Warshaw, P.R. (1989): User Acceptance of Computer Technology: A Comparison of Two Theoretical Models. In: Management Science, 35. 8. 982-1003. p. doi: 10.1287/mnsc.35.8.982

Drennan, B. (2003): E-banking history. [online] <URL: http://www.drennangroup.com/ history.html>

El-Qirem I.A. (2013): Critical Factors Influencing E-Banking Service Adoption in Jordanian Commercial Banks: A Proposed Model. In: International Business Research; 6. 3. 229-236. p. doi: 10.5539/ibr.v6n3p229

Ernovianti, E., Mat, N.K., Kassim, U., Rashid, R. (2012). The Usage of Internet Banking Service among Higher Learning Students in Malaysia. In: American Journal of Economics, 2. 4. 105-108. p. doi: 10.5923/j.economics.20120001.24

Esmaeili A., Horri M.S.. (2014): Efficiency evaluation of customer satisfaction index in e-banking using the fuzzy data envelopment analysis. In: Management Science Letters, 4. 1. 71-86. p. doi: 10.5267/j.msl.2013.11.032

Esmaeili, M.R., Nazarpoori, A.H., Najafi, M. (2013): An investigation on loyalty formation model in e-banking customers: A case study of banking industry. In: Management Science Letters, 3. 3. 903-912. p. doi: 10.5267/j.msl.2013.01.030

Faroughian, F.F., Kalafatis, S.P., Ledden, L., Samouel P. Tsogas M.H. (2012): Value and risk in business-to-business e-banking. In: Industrial Marketing Management, 41. 1. 68-81. p. doi: 10.1016/j.indmarman.2011.11.012

FFEC (Federal Financial Examination Council) (2003): E-banking Handbook, [online] <URL: http://www.ffiec.gov/ffiecinfobase/ booklets/e_banking/e_banking.pdf>

Fishbein, M.A., Ajzen, I. (1975): Belief, Attitude, Intention and Behavior: An Introduction to Theory and Research. Reading, MA: Addison-Wesley, 578. p. 
Fitzergelad, K. (2004): An Investigation Into People's Perceptions of Online Banking. [online] <URL: http://staffweb.itsligo.ie/staff/eward/ebus0203/ Discussion topics/Online Banking.htm>

Floh, A., Treiblmaier, H. (2006): What Keeps The E-Banking Customer Loyal? A Multigroup Analysis of the Moderating Role of Consumer Characteristics on ELoyalty in the Financial Service Industry. In: SSRN Electronic Journal, 7. 2. doi: 10.2139/ ssrn.2585491

Foon, Y.S., Fah, B.C.Y. (2011): Internet banking adoption in Kuala Lumpur: an application of UTAUT model. In: International Journal of Business and Management, 6. 4. 161-167. p. doi: 10.5539/ijbm.v6n4p161

Gbadeyan, R.A., Akinyoseye-Gbonda, O.O. (2011): Customers' Preference For EBanking Services: A Case Study Of Selected Banks In Sierra Leone. In: Australian Journal of Business and Management Research, 1. 4. 108-116. p.

Gefen, D. (2002): Customer loyalty in e-commerce. In: Journal of the Association for Information Systems, 3. 1. 27-53. p. doi: 10.17705/1jais.00022

Hamadi, C. (2011): The Moderating Role of Need for Personal Interaction in the Relationship between E-Quality, E-Satisfaction and Commitment "Case of Moroccan E-Banking Users”. In: IBIMA Business Review, 2011. 1-11. p. doi: 10.5171/2011.625728

Hanafizadeh, P., Keating, B.W. Khedmatgozar, H.R. (2014): A systematic review of Internet banking adoption. In: Telematics and Informatics, 31. 3. 492-510. p. doi: $10.1016 /$ j.tele.2013.04.003

Hoehle, H., Kude, T., Huff S., Popp K. (2017): Service-Channel Fit Conceptualization and Instrument Development: A Mixed Methods Study in the Context of Electronic Banking. In: Business \& Information Systems Engineering, 59. 2. 97-110. p. doi: 10.1007/s12599-015-0415-z

Howcroft, B., Hamilton, R., Hewer, P. (2002): Consumer attitude and the usage and adoption of home-based banking in the United Kingdom. In: International Journal of Bank Marketing, 20. 3. 111-121. p. doi: 10.1108/02652320210424205

Hussien, M.I., Abd El Aziz, R. (2013): Investigating e-banking service quality in one of Egypt's banks: a stakeholder analysis. In: The TQM Journal, 25. 5. 557-576. p. doi: 10.1108/tqm-11-2012-0086

Jacoby, J., Kaplan, L.B. (1972): The components of perceived risk. In: SV Proceedings of the 3rd Annual Conference of the Association for Consumer Research, Venkatesan, M. (ed.) Chicago, IL : Association for Consumer Research, 382-393. p.

Jalal, A., Marzooq, J., Nabi, H. (2011): Evaluating the Impacts of Online Banking Factors on Motivating the Process of E-banking. In: Journal of Management and Sustainability, 1. 1. 32-42. p. doi: 10.5539/jms.v1n1p32

Johar, M.G.M., Awalluddin, J.A.A. (2011): The Role Of Technology Acceptance Model In Explaining Effect On E-Commerce Application System. In: International Journal of Managing Information Technology, 3. 3. 1-14. p. doi: 10.5121/ijmit.2011.3301 
Johnson, D. (2014): Opting Out: The Effects of Consumer Information Sharing Concerns on Perceived Value in E-Banking Relationships. In: International Journal of Marketing Studies, 6. 2. 1-14. p. doi: 10.5539/ijms.v6n2p1

Lee, C.P., Mattila, M., Shim, J.P. (2007): An exploratory study of mobile banking systems resistance in Korea and Finland. Americas Conference on Information Systems. Keystone, August 2007.

Lee, G.G., Lin, H.F. (2005): Customer perceptions of e-service quality in online shopping. In: International Journal of Retail and Distribution Management, 33(2/3), 161-176. p. doi: 10.1108/09590550510581485

Liao, Z., Chung, M.T. (2002): Internet-based e-banking and consumer attitudes: An empirical study. In: Information \& Management, 39. 4. 283-295. p. doi: 10.1016/s0378-7206(01)00097-0

Lymperopoulos, C., Chaniotakis I.E. (2004): Branch employees' perceptions towards implications of e-banking in Greece. In: International Journal of Retail \& Distribution Management, 32. 6. 302-311. p. doi: 10.1108/09590550410538006

Ma, Z., Zhao, J. (2012): Evidence on E-Banking Customer Satisfaction in the China Commercial Bank Sector. In: Journal of Software, 7. 4. 927-933. p. doi: 10.4304/jsw.7.4.927-933

Mansour, I., Eljelly, A., Abdullah, A. (2016). Consumers' attitude towards e-banking services in Islamic banks: the case of Sudan. In: Review of International Business and Strategy, 26. 2. 244-260. p. doi: 10.1108/ribs-02-2014-0024

Mehrad D. Mohammadi, S. (2016): Word of Mouth impact on the adoption of mobile banking in Iran. In: Telematics and Informatics, 34. 7. 1351-1363. p. doi: 10.1016/j.tele.2016.08.009

Mirza, A.P., Beheshti, H., Wallstrom, A., Mirza, O.P. (2009): Adoption of Internet Banking by Iranian Consumers: An Empirical Investigation. In: Journal of Applied Sciences, 9. 14. 2567-2575. p. doi: 10.3923/jas.2009.2567.2575

Moga, L.M., Nor, K.M. Mitrica, E. (2012): E-banking Adoption in Romanian Companies: Determining Factors and Model. In: Communications of the IBIMA, 2012. 7. p. doi: 10.5171/2012.385699

Montazemi, A.R., Qahri-Saremi, H.Q. (2013): Factors Affecting Internet Banking Pre-usage Expectation Formation. Wailea: 2013 46 th Hawaii International Conference on System Sciences, 7-10 Jan. 2013. doi: 10.1109/hicss.2013.231

Montazemi, A.R., Qahri-Saremi, H. (2015): Factors affecting adoption of online banking: A meta-analytic structural equation modeling study. In: Information \& Management, 52. 2. 210-226. p. doi: 10.1016/j.im.2014.11.002

Moore, G.C., Benbasat, I. (1991): Development of an instrument to measure the perceptions of adopting an information technology innovation. In: Information Systems Research, 2. 3. 192-222. p. doi: 10.1287/isre.2.3.192

Moutinho, L., Smith, A. (2000): Modelling bank customer satisfaction through mediation of attitudes towards human and automated banking. In: International Journal of Bank Marketing, 18. 3. 124-134. p. doi: 10.1108/02652320010339699

Oshlyansky, L., Cairns, P., and Thimbleby, H. (2007): Validating the Unified Theory of Acceptance and Use of Technology (UTAUT) tool cross-culturally. United Kingdom: Proceedings of the $21^{\text {st }}$ British HCI group annual conference on 
people and computers: HCI... But not as we know it - Volume 2, 3-7 September 2007, 83-86. p.

Parasuraman, A., Zeithaml, V.A., Malhotra, A. (2005): E-S-Qual: a multiple-item scale for assessing electronic service quality. In: Journal of Service Research, 7. 3. 213-233. p. doi: 10.1177/1094670504271156

Poon, W-C. (2007): Users' adoption of e-banking services: the Malaysian perspective. In: Journal of Business \& Industrial Marketing, 23. 1. 59-69. p. doi: 10.1108/08858620810841498

Raida, R.E., Néji, B. (2013): The Adoption of the E-Banking: Validation of the Technology Acceptance Model. In: Technology and Investment, 4. 3. 197-203. p. doi: 10.4236/ti.2013.43023

Rodrigues, L.F., Oliveira, A., Costa, C.J. (2016): Does ease-of-use contributes to the perception of enjoyment? A case of gamification in e-banking. In: Computers in Human Behavior, 61. 114-126. p. doi: 10.1016/j.chb.2016.03.015

Salhieh, L., Abu-Doleh, J. Hijazi, N. (2011): The assessment of e-banking readiness in Jordan. In: International Journal of Islamic and Middle Eastern Finance and Management, 4. 4. 325-342. p. doi: 10.1108/17538391111186564

Sanayei A., Saneian, Z.S. (2013): Analysis of Traditional Attributes and Website Attributes in Order to Improve Customers Trust in Electronic Banking (The Case of Customers of Mellat Bank, Iran, Shiraz Branch). In: International Journal of Academic Research in Business and Social Sciences November, 3. 11. 76-89. p. doi: 10.6007/ijarbss/v3-i11/321

Sanchez-Franco, M.J. (2009): The Moderating Effects of Involvement on the Relationships Between Satisfaction, Trust and Commitment in e-Banking. In: Journal of Interactive Marketing, 23. 3. 247-258. p. doi: 10.1016/j.intmar.2009.04.007

Sathye, M. (1999): Adoption of internet banking by Australian consumers: an empirical investigation. In: International Journal of Bank Marketing, 17. 7. 324334. p. doi: 10.1108/02652329910305689

Shaemi A., Saneian, Z . (2014): Building trust in e-banking and its effect on positive word-of-mouth advertising. In: Management Science Letters, 4. 5. 967-976. p. doi: $10.5267 /$ j.msl.2014.3.016

Sohail, M.S., Shanmugham, B. (2002): E-banking and customer preferences in Malaysia: An empirical investigation. In: Information Sciences, 150. 3-4. 207217. p. doi: 10.1016/s0020-0255(02)00378-x

Tan, M., Thompson, S.H.T. (2000): Factors influencing the adoption of Internet banking. In: Journal of the Association for Information Systems. 1. 1. 1-43. p.

Tarhini, A., Hone, K., Liu, X. (2014): The effects of individual differences on e-learning users' behaviour in developing countries: A structural equation model. In: Computers in Human Behavior, 41. 153-163. p. doi: 10.1016/j.chb.2014.09.020

Thornton, J., White, L. (2001): Customer orientations and usage of financial distribution channels. In: Journal of Services Marketing, 15. 3. 168-185. p. doi: 10.1108/08876040110392461 
Venkatesh, V., Brown, A. (2001): A longitudinal investigation of personal computers in homes: adoption determinants and emerging challenges. In: MIS Quarterly, 25. 1. 71-102. p. doi: 10.2307/3250959

Venkatesh, V., Morris, M.G., Davis, G.B., Davis F.D (2003): User Acceptance of Information Technology: Toward a Unified View. In: MIS Quarterly, 27. 3. 425-478. p. doi: 10.2307/30036540

Venkatesh, V., Thong, J.Y.L., Xu, X. (2012): Consumer acceptance and use of information technology: Extending the unified theory of acceptance and use of technology. In: MIS Quarterly, 36. 1. 157-178. p. doi: 10.2307/41410412

Wahab, S., Noor, N.A.M. Ali, J. (2009): Technology Trust and E-Banking Adoption: The Mediating Effect of Customer Relationship Management Performance. In: The Asian Journal of Technology Management, 2. 2. 40-49. p.

Yousefi, N., Nasiripour, A.A. (2015): A proposed model of e-trust for electronic banking. In: Management Science Letters, 5. 1029-1040. p. doi: 10.5267/j.msl.2015.8.008

Yu C-S., Asgarkhani, M. (2015): An investigation of trust in e-banking. In: Management Research Review, 38. 12. 1267-1284. p. doi: 10.1108/mrr-092014-0210

Yuen, Y.Y., Yeow, P.H.P., Lim, N., Saylani, N. (2010): Internet banking adoption: Comparing developed and developing countries. In: Journal of Computer Information Systems, 51. 1. 52-61. p. doi: 10.1080/08874417.2010.11645449

Zadeh, V.A., Zangeneh, G.H.K., Azad, N. (2014): Investigating important factors influencing electronic banking for export development. In: Management Science Letters, 4. 1. 123-126. p. doi: 10.5267/j.msl.2013.11.025

Zeithaml, V.A. (1988): Consumer perceptions of price, quality, and value: A meansend model and synthesis of evidence. In: The Journal of Marketing, 52. 3. 2-22. p. doi: $10.1177 / 002224298805200302$

Zeithaml, V.A., Parasuraman, A., Malhotra, A. (2002): Service quality delivery through web sites: a critical review of extant knowledge. In: Journal of the Academy of Marketing Science, 30. 4. 362-375. p. doi: 10.1177/009207002236911

Corresponding author:

\section{Yadgar Hama KHAN}

University of Sulaimani

College of Administrations and Economics

Sulaimani, Iraqi Kurdistan Region PO Box 334

e-mail: yadgarhamakhan@gmail.com 


\section{APPENDICES}

\section{Appendix 1}

\section{Summary of the applied theory, unit of samples and results}

\begin{tabular}{|c|c|c|c|}
\hline Authors \& year & Theories & $\begin{array}{l}\text { Unit of analysis } \\
\text { (Questionnaire) }\end{array}$ & Results \\
\hline $\begin{array}{l}\text { Yu and Asgarkhani (2015), } \\
\text { Arayesh (2015), Ahmadi and } \\
\text { Afrouzi (2012), Ahmad and Al- } \\
\text { Zu'bi (2011), Hamadi (2011), } \\
\text { Hussien and Abd El Aziz } \\
\text { (2013), Azad, Abbaszadeh, } \\
\text { Rikhtegar and Asgari (2013), } \\
\text { Azad, Seyedaliakbar, Mousavirad } \\
\text { and Mousavirad (2013), Zadeh, } \\
\text { Zangeneh and Azad (2014), } \\
\text { Johnson (2014), Lymperopoulos } \\
\text { and Chaniotakis (2004), } \\
\text { Sanchez-Franco (2009), Esmaeili } \\
\text { and Horri (2014). }\end{array}$ & $\begin{array}{l}\text { (SDM) Self- } \\
\text { developed } \\
\text { model. }\end{array}$ & $\begin{array}{l}\text { Data collections } \\
\text { were based on } \\
\text { questionnaires with } \\
\text { different } \\
\text { populations } \\
\text { (customers 11, } \\
\text { teachers 1, Bank } \\
\text { employees 1). }\end{array}$ & $\begin{array}{l}\text { Those studies built an own perspective } \\
\text { model based on some variables which is } \\
\text { each of them from different theories, } \\
\text { the reason is related to the locations of } \\
\text { studies because of different situations } \\
\text { existing over there ( such as Customers } \\
\text { perspectives and culture, Technology } \\
\text { environment, Level of intention to use } \\
\text { E-banking). Those variables (such as } \\
\text { Trust, Technical and Legal factors, } \\
\text { security, accessibility, speed, fees, } \\
\text { charges, positive Word of mouth } \\
\text { (WOM), Service quality), were } \\
\text { introduced to understand the level of } \\
\text { acceptance or adoption of E-banking. }\end{array}$ \\
\hline Yousefi and Nasiripour (2015) & $\begin{array}{l}\text { CTT, TAM, } \\
\text { TOE }\end{array}$ & $\begin{array}{l}177 \text { electronic } \\
\text { service customers in } \\
\text { number of banks in } \\
\text { the city of Karaj, } \\
\text { Iran. }\end{array}$ & $\begin{array}{l}\text { Trust and features of banks such as } \\
\text { reputation, size and dependence on } \\
\text { government, have had the greatest } \\
\text { effect on customer's trust in e-banking } \\
\text { services. }\end{array}$ \\
\hline $\begin{array}{l}\text { Esmaeili, Nazarpoori and Najafi } \\
\text { (2013) }\end{array}$ & $\begin{array}{l}\text { Customer loyalty } \\
\text { formation. }\end{array}$ & \begin{tabular}{|l|}
160 electronic \\
customers of Mellat \\
Bank.
\end{tabular} & $\begin{array}{l}\text { Satisfaction, reputation \& trust are the } \\
\text { most influential components affecting } \\
\text { customer loyalty formation. }\end{array}$ \\
\hline Floh and Treiblmaier (2006) & $\begin{array}{l}\text { Customer } \\
\text { loyalty, TAM, } \\
\text { UTAUT, CTT. }\end{array}$ & $\begin{array}{l}\text { 2,000 customers of } \\
\text { an Austrian online } \\
\text { bank were } \\
\text { questioned. }\end{array}$ & $\begin{array}{l}\text { Loyalty is therefore significantly } \\
\text { affected by satisfaction and trust. } \\
\text { Additionally, effects of Web site quality } \\
\text { on service quality, satisfaction and trust } \\
\text { were observed, as well as a significant } \\
\text { effect of service quality on overall } \\
\text { satisfaction. }\end{array}$ \\
\hline Wahab, Noor and Ali (2009) & \begin{tabular}{l|} 
(CRM)Customer \\
Relationship \\
Management) \\
performance. \\
\end{tabular} & $\begin{array}{l}307 \text { academic staff } \\
\text { of three universities } \\
\text { in the northern state } \\
\text { of Malaysia. }\end{array}$ & $\begin{array}{l}\text { The relationship between perceived } \\
\text { trust and electronic banking adoption is } \\
\text { fully mediated by the customer } \\
\text { relationship management performance. }\end{array}$ \\
\hline $\begin{array}{l}\text { Faroughian, Kalafatis, Ledden, } \\
\text { Samouel and Tsogas (2011) }\end{array}$ & \begin{tabular}{l|} 
Information \\
system security \\
manager (ISSM), \\
PRT, DOI \\
\end{tabular} & $\begin{array}{l}\text { A postal survey of } \\
167 \text { UK-based SME } \\
\text { organisations. }\end{array}$ & $\begin{array}{l}\text { Performance risk and financial risk are } \\
\text { found to be significant determinants of } \\
\text { benefits, while psychological risk } \\
\text { impacts on perceptions of sacrifices. }\end{array}$ \\
\hline $\begin{array}{l}\text { Hoehle, Kude, Huff and Popp } \\
\text { (2017) }\end{array}$ & SDM, TTF & $\begin{array}{l}340 \text { consumers in } \\
\text { New Zealand. }\end{array}$ & $\begin{array}{l}\text { The results confirmed that all the } \\
\text { weights associated with the service } \\
\text { channel fit (SCF) were statistically } \\
\text { significant. }\end{array}$ \\
\hline $\begin{array}{l}\text { Aderonke A and Charles K } \\
\text { (2010), Jalal, Marzooq and Nabi } \\
\text { (2011), Abadi and Nematizadeh } \\
\text { (2012), Moga, Nor and Mitrica } \\
\text { (2012), Raida and Néji (2013), } \\
\text { Alikhani and Davarzani (2014), } \\
\text { Mansour, Eljelly and Abdullah } \\
\text { (2016), Rodrigues, Oliveira and } \\
\text { Costa (2016). }\end{array}$ & TAM & $\begin{array}{l}\text { Data collections } \\
\text { were based on } \\
\text { questionnaires with } \\
\text { different } \\
\text { populations } \\
\text { (customers 7, } \\
\text { Business Leaders 1). }\end{array}$ & $\begin{array}{l}\text { TAM is still the most widely used theory } \\
\text { for E-banking with other External } \\
\text { Variables (such as Security, Technical } \\
\text { resources, Trust, etc.) have been used to } \\
\text { determine whether TAM has significant } \\
\text { effect or not on the intention to use E- } \\
\text { banking. }\end{array}$ \\
\hline
\end{tabular}


Khan: A Short Review of the Electronic Banking System

\begin{tabular}{|c|c|c|c|}
\hline El-Qirem (2013) & $\begin{array}{l}\text { TAM \& } \\
\text { UTAUT }\end{array}$ & \begin{tabular}{|l|}
3000 of all bank \\
account holders \\
who make use of E- \\
Banking in Jordan. \\
\end{tabular} & $\begin{array}{l}\text { The result showed that the model was } \\
\text { accepted, and account essential factor } \\
\text { influence E-Banking services adoption } \\
\text { in the Jordanian commercial banks. }\end{array}$ \\
\hline Sanayei \& Saneian (2013) & TAM, IDT & $\begin{array}{l}383 \text { customers of } \\
\text { Mellat bank, Shiraz } \\
\text { Branch in Iran. }\end{array}$ & $\begin{array}{l}\text { Both traditional and website bank } \\
\text { characteristics influence the customers' } \\
\text { significant influence on the trust in } \\
\text { electronic banking. Also, the } \\
\text { coordinator role of traditional service } \\
\text { quality in relation to traditional } \\
\text { characteristics with trust in electronic } \\
\text { banking was rejected. }\end{array}$ \\
\hline $\begin{array}{l}\text { Salhieh, Abu-Doleh and Hijazi } \\
\text { (2011) }\end{array}$ & TAM, SDM & $\begin{array}{l}\text { The population of } \\
\text { the study includes } \\
18 \text { commercial and } \\
\text { Islamic banks in } \\
\text { Jordan. In total, } 60 \\
\text { questionnaires were } \\
\text { distributed to } \\
\text { managers in five } \\
\text { departments in the } \\
\text { banks, also, } 30 \\
\text { questionnaires were } \\
\text { distributed to IT } \\
\text { managers in the } \\
\text { bank, finally } 150 \\
\text { questionnaires were } \\
\text { distributed to ten } \\
\text { customers from } \\
\text { each bank. }\end{array}$ & $\begin{array}{l}\text { This study used three branchesds to } \\
\text { propose a framework that can assesses } \\
\text { E-Banking readiness: perceptions of } \\
\text { bankers, perceptions of customers, and } \\
\text { IT infrastructure in banks. }\end{array}$ \\
\hline $\begin{array}{l}\text { Asgari, Ahmadi, Shamlou, } \\
\text { Farokhi and Farzin (2014) }\end{array}$ & $\begin{array}{l}\text { TAM, SDM, } \\
\text { ISSM }\end{array}$ & $\begin{array}{l}384 \text { people were } \\
\text { considered among } \\
\text { all customers of } \\
\text { Hekmat Iranian } \\
\text { bank. }\end{array}$ & $\begin{array}{l}\text { The result concluded that variables of } \\
\text { completing the banking services, } \\
\text { security, privacy and accountability and } \\
\text { designing website will have a significant } \\
\text { positive impact on e-loyalty and finally } \\
\text { recommendations are presented } \\
\text { according to the research findings. } \\
\end{array}$ \\
\hline Shaemi and Saneian (2014) & $\begin{array}{l}\text { TAM, TOE, } \\
\text { SDM }\end{array}$ & $\begin{array}{l}384 \text { customers of } \\
\text { Shiraz Mellat bank } \\
\text { branches. }\end{array}$ & $\begin{array}{l}\text { The result showed that both traditional } \\
\text { characteristics of bank and website } \\
\text { characteristics rather have positive } \\
\text { effects on customers' trust in electronic } \\
\text { banking, which increase word of mouth } \\
\text { advertising positively. }\end{array}$ \\
\hline $\begin{array}{l}\text { Ayo, Oni, Adewoye and Eweoya } \\
(2016)\end{array}$ & $\begin{array}{l}\text { TAM, TPB, } \\
\text { ISSM, DOI }\end{array}$ & 254 e-banking users. & $\begin{array}{l}\text { The result reveals that perceived e- } \\
\text { service quality has a strong influence on } \\
\text { customer satisfaction and use of e- } \\
\text { banking, }\end{array}$ \\
\hline $\begin{array}{l}\text { Ahmad, Rashid, Masood and } \\
\text { Mujeeb (2011) }\end{array}$ & $\begin{array}{l}\text { TAM, TRA } \\
\& \text { TPB }\end{array}$ & \begin{tabular}{|l|} 
\\
40 staff members \\
and 4 customers as a \\
sample. \\
\end{tabular} & $\begin{array}{l}\text { Customers are not ready to adopt new } \\
\text { technology that is why their satisfaction } \\
\text { level with E-Banking is low. Internet } \\
\text { speed and government policies are not } \\
\text { supportive for E-Banking in Pakistan. } \\
\text { Due to the lack of trust in technology } \\
\text { and low computer literacy rate, } \\
\text { customers hesitate to adopt new } \\
\text { technology. In order to promote IT } \\
\text { culture in Pakistan, the government has } \\
\text { to reduce the Internet rate to promote } \\
\text { the benefits of E-Banking in thje media } \\
\text { so that more users get facilitation from } \\
\text { E-Banking services. }\end{array}$ \\
\hline
\end{tabular}




\begin{tabular}{|c|c|c|c|}
\hline Sohail \& Shanmugham (2002) & $\begin{array}{l}\text { TAM, UTAUT, } \\
\text { CTT, IDT. }\end{array}$ & $\begin{array}{l}300 \text { Students who } \\
\text { were pursuing their } \\
\text { studies and staff at } \\
\text { two leading } \\
\text { universities in } \\
\text { Malaysia. }\end{array}$ & $\begin{array}{l}\text { There are no significant differences } \\
\text { between the age and educational } \\
\text { qualifications of the electronic and } \\
\text { conventional banking users, some } \\
\text { differences exist on other demographic } \\
\text { variables. Further analysis reveals that } \\
\text { accessibility of Internet, awareness of e- } \\
\text { banking, and customers' reluctance to } \\
\text { change are the factors that significantly } \\
\text { affect the usage of e-banking in } \\
\text { Malaysia. The cost of computers and } \\
\text { Internet access, and security concerns of } \\
\text { e-banking do not significantly influence } \\
\text { the usage of E-Banking in Malaysia. } \\
\end{array}$ \\
\hline Ma and Zhao (2012) & $\begin{array}{l}\text { TAM, UTAUT, } \\
\text { DOI }\end{array}$ & $\begin{array}{l}198 \text { volunteers of } \\
\text { Chinese E-banking } \\
\text { users. }\end{array}$ & $\begin{array}{l}\text { The link between website quality and E- } \\
\text { banking customer satisfaction in } \\
\text { Chinese e-banking industry was } \\
\text { significant. }\end{array}$ \\
\hline Poon (2007) & $\begin{array}{l}\text { TAM, UTAUT, } \\
\text { IDT }\end{array}$ & $\begin{array}{l}324 \text { usable } \\
\text { responses (bank } \\
\text { customer). }\end{array}$ & $\begin{array}{l}\text { Privacy and security are the major } \\
\text { sources of dissatisfaction, which have } \\
\text { momentously impacted users' } \\
\text { satisfaction. Meanwhile, accessibility, } \\
\text { convenience, design and content are } \\
\text { sources of satisfaction. Besides, the } \\
\text { speed, product features availability, and } \\
\text { reasonable service fees and charges, as } \\
\text { well as the bank's operation } \\
\text { management factor are critical to the } \\
\text { success of the e-banks. }\end{array}$ \\
\hline Capece and Campisi (2013) & TPB & $\begin{array}{l}495 \text { real users of } \mathrm{E}- \\
\text { Banking services in } \\
\text { Italy. }\end{array}$ & $\begin{array}{l}\text { The results show that the proposed } \\
\text { model has good explanatory power and } \\
\text { confirms its robustness in predicting } \\
\text { customers' intentions to use such } \\
\text { services. }\end{array}$ \\
\hline
\end{tabular}




\section{Appendix 2}

\section{Summary of researches per countries and Results}

\begin{tabular}{|c|c|c|}
\hline Authors \& year & Country & Summary of result \\
\hline Floh and Treiblmaier (2006) & Austria & $\begin{array}{l}\text { Loyalty is therefore significantly affected by satisfaction } \\
\text { and trust. Additionally, effects of Website quality on } \\
\text { service quality, satisfaction and trust were observed, as } \\
\text { well as there was a significant effect of service quality on } \\
\text { overall satisfaction. }\end{array}$ \\
\hline Jalal, Marzooq and Nabi (2011) & Bahrain & $\begin{array}{l}\text { Security and privacy factors play an important part in } \\
\text { determining the users' acceptance of e-banking services } \\
\text { with respect to different segmentation of age group, } \\
\text { income level and level of education. }\end{array}$ \\
\hline Ma and Zhao (2012) & China & $\begin{array}{l}\text { The link between website quality and E-banking customer } \\
\text { satisfaction in Chinese e-banking industry was significant. }\end{array}$ \\
\hline Hussien and Abd El Aziz (2013) & Egypt & $\begin{array}{l}\text { Service quality has significant effect on customer } \\
\text { satisfaction. Bank could be considered a success story that } \\
\text { provides a guide line for decision makers in banks that are } \\
\text { less fortunate in providing high service quality, thus help } \\
\text { them address their customers' needs better. }\end{array}$ \\
\hline Lymperopoulos and Chaniotakis (2004) & Greek & $\begin{array}{l}\text { The result provided evidence of the relationship that } \\
\text { exists among the perceptions, the personal characteristics } \\
\text { of the respondents and the organizational characteristics } \\
\text { of their banks. }\end{array}$ \\
\hline $\begin{array}{l}\text { Abadi and Nematizadeh (2012), } \\
\text { Ahmadi and Afrouzi (2012), Azad, } \\
\text { Abbaszadeh, Rikhtegar and Asgari } \\
\text { (2013), Azad, Seyedaliakbar, } \\
\text { Mousavirad and Mousavirad (2013), } \\
\text { Esmaeili, Nazarpoori and Najafi (2013), } \\
\text { Sanayei \& Saneian (2013), Zadeh, } \\
\text { Zangeneh and Azad (2014), Asgari, } \\
\text { Ahmadi, Shamlou, Farokhi and Farzin } \\
\text { (2014), Esmaeili and Horri (2014), } \\
\text { Alikhani and Davarzani (2014), Shaemi } \\
\text { and Saneian (2014), Yousefi and } \\
\text { Nasiripour (2015), Arayesh (2015). }\end{array}$ & Iran & $\begin{array}{l}\text { Iran is considered to be a developing country and E- } \\
\text { banking has left the acceptance step to adoption step, that } \\
\text { is why in those studies consider some factors (such as } \\
\text { advanced services, attitude, compatibility with internet } \\
\text { technology, consistency, contextual, convenient, cost } \\
\text { control, culture, customer awareness, customer loyalty } \\
\text { formation, design, easy to use, enjoyable, facilities, } \\
\text { feasibility, habit, information knowledge, infrastructure, } \\
\text { internet knowledge, methods, perceived usefulness, } \\
\text { perceived value, reputation, satisfaction, security, self- } \\
\text { efficiency computer, service quality, the role of } \\
\text { government and trust) influenced positively the adoption } \\
\text { of electronic banking in Iran. }\end{array}$ \\
\hline Capece and Campisi (2013) & Italy & $\begin{array}{l}\text { The results show that the proposed model has good } \\
\text { explanatory power and confirms its robustness in } \\
\text { predicting customers' intentions to use such services. }\end{array}$ \\
\hline $\begin{array}{l}\text { Salhieh, Abu-Doleh and Hijazi (2011), } \\
\text { Ahmad and Al-Zu'bi (2011), El-Qirem } \\
\text { (2013). }\end{array}$ & Jordan & $\begin{array}{l}\text { Technological aspects and IT employees' skills are } \\
\text { paramount concerns, accessibility, convenience, security, } \\
\text { privacy, content, design, speed, fees and charges affected } \\
\text { the adoption of E-banking in Jordan as a developing } \\
\text { country. }\end{array}$ \\
\hline $\begin{array}{l}\text { Sohail \& Shanmugham (2002), Poon } \\
\text { (2007), Wahab, Noor and Ali (2009). }\end{array}$ & Malaysia & $\begin{array}{l}\text { There are no significant differences between the age and } \\
\text { educational qualifications of the electronic and } \\
\text { conventional banking users, some differences exist on } \\
\text { other demographic variables. Further analysis reveals that } \\
\text { accessibility of Internet, awareness of E-banking, and } \\
\text { customers' reluctance to change are the factors that } \\
\text { significantly affected the usage of e-banking in Malaysia. } \\
\text { The cost of computers and Internet access, and security } \\
\text { concerns of E-banking did not significantly influence the } \\
\text { usage of E-Banking in Malaysia in } 2002 \text { but privacy and } \\
\text { security were the major sources of dissatisfaction, which } \\
\text { have momentously impacted users' satisfaction in } 2007 \text {. } \\
\text { The relationship between perceived trust and electronic }\end{array}$ \\
\hline
\end{tabular}




\begin{tabular}{|c|c|c|}
\hline & & $\begin{array}{l}\text { banking adoption is fully mediated by the customer } \\
\text { relationship management performance. }\end{array}$ \\
\hline Hamadi (2011) & Morocco & $\begin{array}{l}\text { The research results showed a positive and significant link } \\
\text { between the electronic quality and satisfaction, also it } \\
\text { showed a significant positive influence of e-satisfaction on } \\
\text { commitment, but one the other hand the results reveal } \\
\text { that a high or low need for personal interaction does not } \\
\text { modify these relationships for Moroccan e-banking users. }\end{array}$ \\
\hline Hoehle, Kude, Huff and Popp (2017) & New Zealand & $\begin{array}{l}\text { The results confirmed that all the weights associated with } \\
\text { the service channel fit (SCF) were statistically significant. }\end{array}$ \\
\hline $\begin{array}{l}\text { Aderonke A and Charles K (2010), Ayo, } \\
\text { Oni, Adewoye and Eweoya (2016). }\end{array}$ & Nigeria & $\begin{array}{l}\text { Banks' customers who are considered the active users of } \\
\text { e-Banking system because it is convenient, easy to use, } \\
\text { time saving and appropriate for their transaction needs. } \\
\text { Also, the network security and the security of the system } \\
\text { in terms of privacy are the major concerns for the users } \\
\text { and constitute hindrance to intending users, perceived e- } \\
\text { service quality has a strong influence on customer } \\
\text { satisfaction and use of e-banking. }\end{array}$ \\
\hline $\begin{array}{l}\text { Ahmad, Rashid, Masood and Mujeeb } \\
\text { (2011) }\end{array}$ & Pakistan & $\begin{array}{l}\text { Customers are not ready to adopt new technology that is } \\
\text { why their satisfaction level with E-Banking is low. } \\
\text { Internet speed and government policies are not } \\
\text { supportive for E-Banking in Pakistan. Due to the lack of } \\
\text { trust in technology and low computer literacy rate, } \\
\text { customers hesitate to adopt new technology. : In order to } \\
\text { promote IT culture in Pakistan, the government has to } \\
\text { reduce the Internet rate, to promote the benefits of E- } \\
\text { Banking on media so that more users get facilitation from } \\
\text { E-Banking services. }\end{array}$ \\
\hline Rodrigues, Oliveira and Costa (2016) & Portugal & $\begin{array}{l}\text { Ease-of-use and enjoyments are interrelated, and both } \\
\text { have influence on e-banking usage. Also a theoretical } \\
\text { ground of the conceptual model was presented, and two } \\
\text { empirical studies were discussed, aimed to analyse the ease } \\
\text { of-use and enjoyment influence on bank customers. }\end{array}$ \\
\hline Moga, Nor and Mitrica (2012) & Romania & $\begin{array}{l}\text { Compatibility, technical resources and self-efficacy have } \\
\text { significant effects on the intention of the managers to use } \\
\text { E-Banking, the results of the study have also shown that } \\
\text { the other three factors, namely perceived usefulness, } \\
\text { accessibility and oberservability did not have significant } \\
\text { effects on the intention to use e-banking among } \\
\text { companies in Romania. }\end{array}$ \\
\hline Sanchez-Franco (2009) & Spain & $\begin{array}{l}\text { Moderating role of customer involvement. The influence } \\
\text { of online satisfaction on commitment was significantly } \\
\text { stronger for highly involved users; conversely, the effect } \\
\text { of satisfaction on trust was weaker. However, customer } \\
\text { trust had a stronger effect on commitment for customers } \\
\text { with high purchase involvement, and a weaker effect for } \\
\text { highly ego involved customers. }\end{array}$ \\
\hline Mansour, Eljelly and Abdullah (2016) & Sudan & $\begin{array}{l}\text { The benefits and ease of use and service quality, whereas } \\
\text { internet customers were influenced by the benefits and } \\
\text { ease of use and credibility of the systems. }\end{array}$ \\
\hline Yu and Asgarkhani (2015) & \begin{tabular}{l|} 
Taiwan and \\
New Zealand
\end{tabular} & $\begin{array}{l}\text { The results indicated that,first of all, not all trusts' } \\
\text { precursors considered by the authors have significant } \\
\text { influence on generating consumers' trust and, secondly } \\
\text { that influential weights of these precursors on building } \\
\text { consumer trust vary across consumers and cultures. } \\
\text { Meanwhile, all factors on the E-Banking side hold greatly } \\
\text { significant influence on consumers' trust in both NZ and } \\
\text { Taiwan cases. }\end{array}$ \\
\hline Raida and Néji (2013) & Tunisia & $\begin{array}{l}\text { The results showed that all hypotheses positively } \\
\text { influenced the intention of use. It means the TAM model } \\
\text { in the context of the use of technology among } \\
\text { professionals was successful. }\end{array}$ \\
\hline
\end{tabular}




\begin{tabular}{|c|c|c|}
\hline $\begin{array}{l}\text { Faroughian, Kalafatis, Ledden, Samouel } \\
\text { and Tsogas (2011) }\end{array}$ & UK & $\begin{array}{l}\text { Performance risk and financial risk are found to be } \\
\text { significant determinants of benefits, while psychological } \\
\text { risk impacts on perceptions of sacrifices. Also evidence } \\
\text { was provided of the different impact of the benefits and } \\
\text { sacrifices components of value on satisfaction, and the } \\
\text { existence of both direct and indirect (through satisfaction) } \\
\text { impact of these components on word-of-mouth and } \\
\text { intention to switch. This is the first documented empirical } \\
\text { investigation of the impact of perceptions of risk in the } \\
\text { study of perceptions of value within the domain of b2b } \\
\text { marketing and consequently offers new insights into the } \\
\text { subject matter. }\end{array}$ \\
\hline Johnson (2014) & USA & $\begin{array}{l}\text { The results showed that when consumers have a high opt- } \\
\text { out belief, the effect of firm commitment to privacy on } \\
\text { perceived value is reduced, the effect of trust in } \\
\text { technology on perceived value is increased and the } \\
\text { negative effect of information ambiguity of perceived } \\
\text { value is attenuated. The findings on the moderating effect } \\
\text { of consumer opt-out belief are consistent with the } \\
\text { predictions of research on idiocentric/allocentric } \\
\text { personality traits. }\end{array}$ \\
\hline
\end{tabular}




\section{Appendix 3}

\section{Summary of the Definition of Factors}

\begin{tabular}{|c|c|c|}
\hline Factor & Definition & Reference \\
\hline $\begin{array}{l}\text { Perceived } \\
\text { Value }\end{array}$ & $\begin{array}{l}\text { The consumer's overall assessment of the utility of a product is based on } \\
\text { perceptions of what is received and what is given. What is received varies } \\
\text { across consumers (i.e., some may want volume, others high quality, still others } \\
\text { convenience) and what is given varies (i.e., some are concerned only with } \\
\text { money spent, others with time and effort), value represents a trade-off of the } \\
\text { salient give and get components. }\end{array}$ & Zeithaml (1988) \\
\hline $\begin{array}{l}\text { Perceived } \\
\text { Usefulness }\end{array}$ & $\begin{array}{l}\text { The degree to which a person believes that using a particular system would } \\
\text { enhance his or her job performance. }\end{array}$ & Davis et al. (1989) \\
\hline $\begin{array}{l}\text { Perceived } \\
\text { Ease of Use }\end{array}$ & $\begin{array}{l}\text { Refers to the degree to which a person believes that using a particular system } \\
\text { would be free from effort. }\end{array}$ & Davis (1989) \\
\hline $\begin{array}{l}\text { Perceived } \\
\text { Credibility }\end{array}$ & $\begin{array}{l}\text { The degree to which a user feels the certainty and pleasant consequences of } \\
\text { using an electronic application service, when there is no financial risk, physical } \\
\text { risk, functional risk, social risk, time-loss risk, opportunity cost risk, and } \\
\text { information risk. }\end{array}$ & $\begin{array}{l}\text { Jacoby and } \\
\text { Kaplan }(1972)\end{array}$ \\
\hline $\begin{array}{l}\text { Electronic } \\
\text { Quality }\end{array}$ & $\begin{array}{l}\text { It includes five dimensions including ease of usage, designing website, } \\
\text { ordering, responding and trust. Service quality is also defined as a customer's } \\
\text { belief or attitude concerning the rate of service superiority in the bank } \\
\text { environment }\end{array}$ & $\begin{array}{l}\text { Al-Hawari et al. } \\
(2009)\end{array}$ \\
\hline $\begin{array}{l}\text { Customer } \\
\text { Satisfaction }\end{array}$ & $\begin{array}{l}\text { It can be described as customers' evaluations of a product or service with } \\
\text { regard to their needs and expectations }\end{array}$ & Bai et al. (2008) \\
\hline Security & $\begin{array}{l}\text { It is defined as the protection of data against accidental or international } \\
\text { disclosure to unauthorized persons, or unauthorized modifications or } \\
\text { destruction }\end{array}$ & $\begin{array}{l}\text { Mirza, et al. } \\
(2009)\end{array}$ \\
\hline Compatibility & $\begin{array}{l}\text { The degree to which an innovation is perceived as being consistent with the } \\
\text { existing values, needs and past experiences of potential adopters. }\end{array}$ & Moore (1991) \\
\hline Attitude & $\begin{array}{l}\text { An individual's positive or negative feelings about performing the target } \\
\text { behaviour. }\end{array}$ & $\begin{array}{l}\text { Fishbein and } \\
\text { Ajzen (1975) } \\
\end{array}$ \\
\hline Awareness & The degree to which consumers' are aware of electronic banking channels. & Lee, et al. (2007) \\
\hline $\begin{array}{l}\text { Accessibility\& } \\
\text { Convenience }\end{array}$ & $\begin{array}{l}\text { Allowing customers to access their bank accounts from any location, at any } \\
\text { time of the day. }\end{array}$ & \begin{tabular}{|l|} 
Tan and \\
Thompson (2000)
\end{tabular} \\
\hline Trust & $\begin{array}{l}\text { The willingness to make oneself vulnerable to actions taken by the trusted } \\
\text { party based on the feeling of confidence or assurance. }\end{array}$ & Gefen,2002. \\
\hline Efficiency & $\begin{array}{l}\text { Refers to the ability of the customer to get to the web site, find their desired } \\
\text { product and information associated with it and to check it out with minimal } \\
\text { effort }\end{array}$ & $\begin{array}{l}\text { Parasuraman et } \\
\text { al. (2005) }\end{array}$ \\
\hline Privacy & $\begin{array}{l}\text { Refers to the degree to which customers believe the site is safe from intrusion } \\
\text { and personal information is protected }\end{array}$ & $\begin{array}{l}\text { Parasuraman et } \\
\text { al. (2005) }\end{array}$ \\
\hline $\begin{array}{l}\text { Information } \\
\text { Ambiguity }\end{array}$ & $\begin{array}{l}\text { Concerned with consumer perception of the lack of clarity of information } \\
\text { about the focal product or service. }\end{array}$ & Johnson (2014) \\
\hline $\begin{array}{l}\text { Information } \\
\text { Quality }\end{array}$ & Identified as one of the main dimensions of website quality. & $\begin{array}{l}\text { Ma and Zhao } \\
(2012)\end{array}$ \\
\hline Design & An important aspect of website quality. & $\begin{array}{l}\text { Ma and Zhao } \\
(2012)\end{array}$ \\
\hline Content & A source of satisfaction. & Poon $(2007)$ \\
\hline Content & $\begin{array}{l}\text { An important dimension that may affect users' intention to adopt e-banking } \\
\text { systems. }\end{array}$ & $\begin{array}{l}\text { Ahmad and Al- } \\
\text { Zu'bi (2011) } \\
\end{array}$ \\
\hline $\begin{array}{l}\text { Fees and } \\
\text { Charges. }\end{array}$ & $\begin{array}{l}\text { One of the attributes that determines consumer's decision on using e-banking } \\
\text { system is fees and charges. }\end{array}$ & Poon (2007) \\
\hline Characteristics & $\begin{array}{l}\text { Such as cost reduction, income increase and customer satisfaction which have } \\
\text { motivated several organizations to benefit from competitive advantage } \\
\text { resulting from electronic commerce. }\end{array}$ & $\begin{array}{l}\text { Shaemi and } \\
\text { Saneian (2014) }\end{array}$ \\
\hline Reliability & $\begin{array}{l}\text { Refers to the extent to which a user believes that he or she can rely on the E- } \\
\text { banking service provided and feel satisfied with it. }\end{array}$ & Lee \& Lin (2005) \\
\hline Size & $\begin{array}{l}\text { The size of the company is the rescue way in which the customer can make a } \\
\text { choice in the trust of firm and the electronic commerce environment. }\end{array}$ & $\begin{array}{l}\text { Shaemi and } \\
\text { Saneian (2014) }\end{array}$ \\
\hline
\end{tabular}

